\title{
EFEKTIVITAS PUZZLE DRILLING METHOD UNTUK PEMAHAMAN AKUNTANSI DAN SISTEM INFORMASI BAGI UMKM
}

\section{EFFECTIVENESS OF DRILLING METHOD PUZZLE ACCOUNTING FOR UNDERSTANDING AND INFORMATION SYSTEM FOR SMES}

\author{
Oleh: \\ Ridwan Nurazi, Siti Aisyah, Husaini, dan Reza Satria Rinaldi \\ Universitas Bengkulu
}

\begin{abstract}
Point of Sales System (POS System) is a recent popular application that able to overcome the daily business operational problems of SMEs, because it provides information on the types of goods, prices, and inventories. This activity introduces POS and training partners to use the application. These activities are successfully implemented a method that is specifically designed for the layman who do not understand the science of accounting. The method is called puzzle drilling method. This method proved to be effective to change the mindset quickly. At first all the partners prepare an income statement with the concept of money going out and money coming, but with this method partners quickly realized their misunderstanding and ignorance about the income statement. Generally this activity has its own benefit for the SMEs owner.
\end{abstract}

Keywords: Point of Sales System, Puzzle Drilling Method, Income Statement

\section{PENDAHULUAN}

Bank Indonesia (2009), untuk menyongsong EAC pada tahun 2015, salah satu yang harus dipersiapkan oleh UMKM di Indonesia adalah persiapan dan peningkatan softskills dalam hal kemampuan menyusun laporan keuangan dan pemanfaatan teknologi informasi. Hasil penelitian yang dilakukan oleh Nurazi, dkk (2009) terhadap 325 Usaha Kecil dan Menengah (UKM) di Kota Bengkulu mengenai financial management dan peningkatan profitabilitas UKM, menyimpulkan bahwa banyak UKM yang tidak mengetahui bagaimana praktik keuangan yang baik. Salah satu implikasi dari hasil penelitian tersebut adalah perlunya pendidikan dan pelatihan yang sesuai kebutuhan UKM. Dari analisis praktik keuangan yang menyangkut laporan dan sistem informasi akuntansi, $62,77 \%$ UKM di Kota Bengkulu hanya membuat laporan laba rugi yang dibuat dan dipersiapkan oleh pemilik dan belum memanfaatkan teknologi dalam sistem informasi akuntansi secara formal. 
Dalam operasional sehari-hari, ujung tombak usaha UMKM adalah penjualan di toko masing-masing. Mitra tidak menggunakan teknologi apapun untuk membantu operasional usaha mereka. Informasi data mengenai unit barang, jenis barang, dan harga barang lebih banyak dikuasai, difahami oleh mitra selaku pemilik. Laporan keuangan lengkap belum pernah mereka buat. Laporan keuangan yang dibuat hanya sebatas uang masuk dan uang keluar saja. Perhitungan laba-rugi juga belum dicatat secara formal menurut standar akuntansi

Pencapaian tujuan mitra untuk memiliki catatan keuangan dan laporan keuangan dipengaruhi oleh lancarnya kegiatan operasional bisnis sehari-hari. Laporan keuangan merupakan output dari suatu proses operasional yang baik. Berdasarkan hasil justifikasi masalah dengan mitra, maka prioritas masalah yang harus ditangani adalah bagaimana sistem operasional bisnis sehari-hari dapat diandalkan sehingga mitra dapat berkonsentrasi kepada tahapan yang lebih luas yaitu memiliki sistem informasi akuntansi yang dapat menghasilkan laporan keuangan bagi usaha mereka. Sistem operasional bisnis yang dibutuhkan oleh mitra adalah bagaimana kegiatan penjualan tidak lagi mengandalkan ingatan pemilik mengenai harga per unit barang atau pun item barang yang dijual.

Kebutuhan mendesak adalah tersedianya sebuah sistem yang mudah digunakan dan tidak terlalu kompleks/sederhana, user friendly, dan murah dari sisi pengadaannya untuk sebuah UMKM tapi mampu mengatasi masalah informasi harga per unit, jumlah item barang tersedia, dan berapa penjualan yang diperoleh setiap hari dan adanya bukti transaksi bisnis untuk mempermudah perhitungan pendapatan harian dan sebagai dokumen awal pencatatan keuangan. Tujuan kegiatan pengabdian berbasis riset ini adalah memberikan pengetahuan dan keterampilan kepada masyarakat/mitra tentang pentingnya peranan sistem informasi khususnya sistem informasi akuntansi yang dapat membantu kelancaran operasional usaha mitra.

\section{METODE PENGABDIAN}

\section{Solusi yang Ditawarkan}

Secara garis besar, solusi atas masalah yang dihadapi oleh mitra dapat dipecahkan dengan mengaplikasikan sistem informasi yang dapat membantu kelancaran operasional dan terlaksananya pencatatan transaksi dan laporan keuangan. Penerapan sebuah sistem informasi pada suatu usaha tidak dapat dilakukan terburu-buru. Penerapan sebuah sistem informasi merupakan suatu rangkaian kegiatan persiapan yang kompleks, dimulai dari kesiapan sumber daya manusianya, kesiapan manajemen (administrasi) usaha, dan supporting facilities seperti perangkat keras berikut perangkat lunaknya, sistem kelistrikan, dan penempatannya.

Untuk mencapai tujuan tersebut, maka kegiatan ini membutuhkan waktu yang cukup panjang. Perkiraan waktu yang dibutuhkan adalah selama 2 (dua) tahun. Mengacu kepada 
prioritas pemecahan masalah, maka pada tahun pertama, tujuan kegiatan adalah terlaksananya pengoperasian sistem sederhana untuk membantu kelancaran operasional. Pada tahun kedua diharapkan sistem informasi yang lengkap dapat dioperasikan pada usaha mitra.

\section{Pengaplikasian "Point Of Sales"}

Ketersediaan sebuah sistem sederhana, user friendly, dan murah dari sisi pengadaannya merupakan kebutuhan yang menjadi prioritas pemecahan masalah mitra saat ini dapat diatasi dengan mengaplikasikan sebuah sistem penjualan, termasuk persediaan, perhitungan utang dan piutang di dalamnya, yang disebut dengan POINT OF SALES "POS".

POS sering digunakan oleh para pengusaha di bidang retail sebagai sebuah sistem untuk menangani sistem penjualan di garda terdepan usaha retail. Aplikasi POS dapat digunakan secara terpisah atau terintegrasi dari aplikasi sistem informasi akuntansi. Aplikasi POS biasanya menyajikan data-data mengenai harga per unit barang, nama barang dan kode barang sehingga memudahkan penggguna (users) aplikasi POS untuk memanggil data yang dibutuhkan jika melakukan eksekusi transaksi di meja kasir.

Pengaplikasian POS pada usaha mitra yang sedang berjalan tidak dapat dilakukan secara langsung. Beberapa persiapan harus dilakukan terlebih dahulu untuk memastikan pengoperasian sistem POS dapat berjalan sukses sejak hari pertama. Persiapan yang harus dilakukan adalah:

\section{Kesiapan Sumber Daya Manusianya}

SDM yang akan terlibat dalam penerapan sistem POS harus memiliki technical skills di bidang akuntansi dan teknologi dan sistem informasi.

2. Supporting facilities untuk pemasangan POS dan pengoperasiannya.

Kelancaran penerapan sistem POS, maka sejumlah fasilitas penunjang harus dipersiapkan oleh mitra. Fasilitas penunjang tersebut adalah:

a. Dokumen yang berisi informasi mengenai produk, nama produk, kode produk, dan jumlah persediaan setiap produk.

b. Ketersediaan minimum sebuah Personal Computer (laptop) yang terhubung dengan sebuah printer khusus untuk transaksi penjualan, sistem kelistrikan dan baterai pendukung kelistrikan.

c. Ketersediaan furnitur (meja dan kursi) dan alat tulis kantor.

Untuk mencapai tujuan pada tahun I, maka metode pendekatan yang digunakan adalah diskusi, ceramah, dan praktik melalui pendidikan dan pelatihan. Rencana kegiatan diwujudkan dalam langkah-langkah sebagai berikut:

\section{Pelatihan Akuntansi Dasar}

Kegiatan Pelatihan Akuntansi Dasar bertujuan untuk memberikan pengetahuan dan technical skills di bidang akuntansi, termasuk di dalamnnya bagaimana pengelolaan 
administrasi keuangan dalam rangka persiapan pengaplikasian kedua sistem pada tahun pertama dan tahun kedua.

Pada pelatihan ini, mitra peserta pelatihan akan diberikan materi mengenai Dasar Akuntansi. Pelatihan difokuskan pada prioritas pemecahan masalah pada tahun pertama, dengan target mitra dapat menyusun Laporan Laba Rugi. Dengan demikian, materi Akuntansi Dasar yang diberikan adalah seputar Akuntansi Pendapatan dan beban Usaha, dan persediaan untuk menghitung harga pokok penjualan (HPP). Materi ini dipersiapkan untuk dapat mengantisipasi kebutuhan keahlian teknis dan dokumen pendukung untuk pengaplikasian sistem "POS".

Pada akhir kegiatan ini, mitra peserta pelatihan telah dapat menyusun laporan Laba Rugi dan memahami akun apa saja yang membentuk laporan keuangan. Produk akhir dari kegiatan ini adalah tersusunnya daftar item barang, yang terdiri dari nama barang, kode barang, harga per unit barang, dan nilai persediaan, termasuk didalamnya kebijakan dalam penjualan misalnya diskon yang diberikan dan harga lain untuk sistem penjualan lain (misalnya grosir).

\section{Pelatihan Pengoperasian Aplikasi POS}

Setelah mitra peserta pelatihan melewati pelatihan Akuntansi Dasar dan menyiapkan dokumen yang berisi informasi mengenai detail barang, daftar utang dan piutang, maka mitra peserta dilatih bagaimana menggunakan aplikasi POS. Pelatihan aplikasi POS dibagi dalam beberapa rangkaian yaitu:

b. Pelatihan setting awal aplikasi POS

Pelatihan setting awal aplikasi POS adalah pelatihan bagaimana membuat sebuah pangkalan data yang biasanya dimulai dengan memasukkan informasi penting tentang usaha, akun-akun tertentu yang diminta sesuai program POS, data item barang, kode barang, nama barang dan jumlah barang yang menjadi saldo persediaan.

c. Simulasi pengoperasian aplikasi POS

Pelatihan dalam bentuk simulasi pengoperasion aplikasi POS adalah suatu pelatihan pengoperasian aplikasi dengan menciptakan lingkungan yang hamper serupa dengan kegiatan operasional mitra sehari-hari. Dimulai dari membuka program di awal hari, terjadinya transaksi, dan penutupan program POS di akhir hari.

d. Pelatihan penanganan jika terjadi masalah terhadap sistem baik yang disebabkan human error maupun system error dan terminasi sistem karena putusnya aliran listrik ke perangkat keras.

\section{Implementasi Aplikasi POS pada Usaha Mitra}

Setelah mitra mahir dalam pelatihan pengoperasian POS, maka sampai pada tahap implementasi Aplikasi POS pada usaha mitra. Kegiatan ini hampir seluruhnya dilakukan oleh mitra. Tim pelaksana hanya menjadi pengawas dalam pengimplementasian untuk memastikan bahwa aplikasi telah terpasang dengan baik. 
Implementasi Aplikasi POS dilakukan satu per satu. Salah satu mitra dipilih dari tingkat kesiapannya untuk melakukan implementasi. Setelah implementasi pada mitra yang pertama dinilai sukses dan berjalan lancar, maka akan dilanjutkan pada mitra berikutnya. Implementasi ini dilaksanakan dengan mengantisipasi kesalahan yang terjadi pada implementasi yang pertama untuk mempercepat proses implementasi berikutnya.

Langkah-langkah yang dilakukan dalam implementasi pada setiap unit usaha mitra adalah:

1. Melakukan instalasi POS sesuai dengan karakteristik usaha mitra.

2. Melakukan setting awal.

3. Memasukkan data item barang, kode barang, nama barang dan jumlah barang yang menjadi saldo persediaan.

4. Persiapan supporting facilities seperti PC atau laptop, printer, kertas printer, dan UPS untuk persiapan jika terjadi pemadaman listrik.

5. Uji coba printer atas transaksi uji coba.

6. POS siap digunakan.

7. Dalam beberapa waktu pengoperasian POS harus terus dipantau dengan meningkatkan komunikasi dengan user dan owner sistem. 


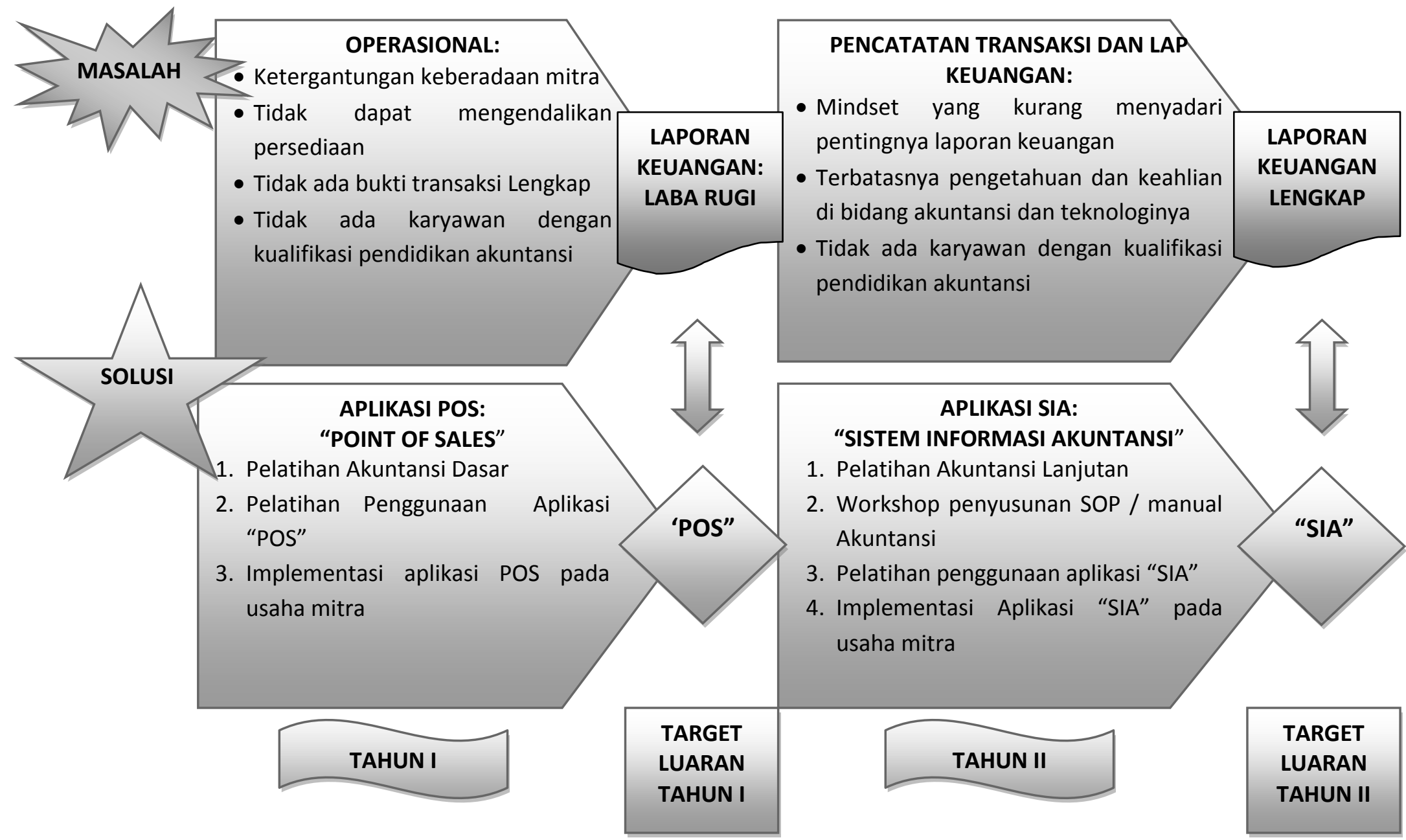

Gambar 1. Flowchart Masalah, Solusi, Rencana dan Langkah Kegiatan 


\section{HASIL DAN PEMBAHASAN}

\section{Deskripsi Kegiatan}

Kegiatan ini dilakukan pada bulan Oktober dan Nopember 2013. Dalam perjalanan kegiatan, terjadi perubahan dan pergantian mitra karena alasan tertentu. Mitra awal kegiatan ini ada 5 mitra, 4 mitra tidak dapat mengikuti rangkaian kegiatan dan ada 6 mitra kegiatan baru. Kegiatan ini dibagi dalam 3 kegiatan utama yaitu:

1. Pelatihan Akuntansi Dasar

Dilaksanakan pada tanggal 9 November 2013 bertempat di Kedai Kopi Aceh, Jl Jend Sudirman Bengkulu. Tempat ini dipilih karena cukup dekat dengan tempat usaha mitra dan memiliki fasilitas lengkap penunjang kegiatan. Kegiatan ini dilaksanakan seharian penuh dari pagi hari hingga sore hari. Jadwal kegiatan terlampir.

2. Pelatihan Penggunaan Aplikasi "POS"

Dilaksanakan bersamaan dengan kegiatan pelatihan akuntansi dasar pada sesi setelah makan siang pada tanggal 9 November 2013 bertempat di Kedai Kopi Aceh, J1. Jend Sudirman Kota Bengkulu.

3. Implementasi aplikasi POS pada usaha mitra

Implementasi aplikasi POS dilaksanakan pada usaha mitra Toko Keluarga pada tanggal 16 dan 17 Nopember 2013 berlokasi di tempat usaha mitra sendiri.

\section{Hasil Kegiatan}

\section{Pelatihan Akuntansi Dasar}

Pelatihan akuntansi dasar dilakukan dengan metode temuan tim pengabdian yang diberi nama puzzle drilling method. Metode ini memanfaatkan media permainan puzzle untuk menggali kemampuan peserta dalam menyusun laporan laba rugi. Puzzle drilling method dilakukan dengan cara:

a. Kegiatan pelatihan tidak diawali dengan pemberian materi akuntansi dasar, tapi diawali dengan menggali persepsi peserta tentang laporan keuangan seperti yang mereka lakukan selama ini tanpa mengetahui terlebih dahulu ilmu akuntansi mengenai hal tersebut.

b. Setiap peserta diberikan satu bundel puzzle yang berisi 22 akun pembentuk laporan keuangan yang dicampur-campur antara akun pembentuk laporan keuangan dan laporan laba rugi. Hal ini dimaksud untuk melihat apakah peserta sudah memiliki kemampuan awal untuk memisahkan akun-akun sesuai dengan penggunaannya

c. Puzzles tersebut disusun pada sebuah papan dari busa dan menempelinya dengan pin yang telah disediakan.

d. Setelah semua peserta selesai menyusun tugas tersebut, hasil pekerjaan peserta disimpan sementara, dan peserta diminta untuk menyimak materi pembelajaran mengenai akuntansi dasar dari pemateri kegiatan. 
e. Pemateri menilai dan mencatat karakteristik penyusunan puzzles untuk setiap peserta sebagai penilaian awal dan menjadi pembanding setelah mereka melakukan perubahan nanti.

f. Setelah menyimak materi tersebut, peserta diminta untuk melihat kembali dan menyusun kembali Puzzles mereka sesuai dengan serapan materi yang mereka terima.

g. Pemateri memberikan tanggapan dan penilaian terhadap puzzles yang telah disusun kembali.

Dari kegiatan ini, terlihat bahwa peserta pada awalnya memiliki konsep yang sama dalam menyusun laporan keuangan yaitu semua berdasarkan konsep uang masuk dan uang keluar saja. Dengan metode pembelajaran yang dirancang khusus untuk orang yang awam laporan keuangan, perubahan pengetahuan dapat diketahui dengan cepat. Pada kegiatan ini, semua peserta dapat memperbaiki laporan laba rugi mereka sesuai teori akuntasi.

\section{Pelatihan Penggunaan Aplikasi "POS"}

Setelah peserta memahami dasar akuntansi untuk aplikasi POS, maka peserta dilatih untuk menyusun data dan dokumen pendukung aplikasi POS yang akan digunakan. Setiap peserta diberi satu lembar kertas yang telah di rancang khusus untuk menyusun data awal yang dibutuhkan yaitu informasi mengenai kode barang, nama barang, dan bagaimana cara cepat menghitung stok yang telah ada (dokumen terlampir). Langkahlangkah kegiatan ini adalah sebagai berikut:

a. Peserta diminta untuk menceritakan praktik perhitungan persediaan dan penomoran atau kode barang yang selama ini mereka lakukan

b. Pemateri akan memberikan tanggapan atas praktik tersebut dan melakukan koreksi dan saran untuk perbaikan dan cara menyusun kode dan nama barang.

c. Peserta diminta untuk berpikir secara kreatif tentang pengelompokan dan pemberian kode barang yang secara profesional.

d. Setelah sampel kode dan nama barang tersedia, pemateri memperagakan sistem POS dengan menggunakan data telah disiapkan oleh peserta.

Aplikasi POS yang digunakan adalah aplikasi Penjualan dan Stok Barang dari Bamboo Media Versi 5 (screen print dari sistem yang digunakan terlampir).

Dari kegiatan ini dapat disimpulkan bahwa mitra tidak menyusun kode barang dan nama barang dengan baik karena pemberian kode barang tidak unik dana tidak mudah untuk menelusurinya. Namun mereka sangat antusias dalam menggunakan demo aplikasi POS yang tersedia. Pemateri juga memberikan informasi tambahan mengenai teknologi terbaru dari sistem POS yaitu POS Mobile yang memanfaatkan teknologi smartphone untuk menggunakan sistem POS. 


\section{Implementasi aplikasi POS pada usaha mitra}

Implementasi aplikasi POS baru dapat dilakukan pada satu mitra saja yang telah siap dengan segala fasilitas pendukung pengaplikasian POS yaitu Toko Keluarga.

\section{Evaluasi Kegiatan}

Evaluasi kegiatan dilakukan berdasarkan rancangan evalusi kegiatan. Evaluasi kegiatan adalah sebagai berikut:

1. Pelatihan Akuntansi Dasar

Kegiatan pelatihan akuntansi dasar dapat dikatakan berhasil karena indikator dan tolok ukur kegiatan tercapai.

2. Pelatihan Penggunaan Aplikasi "POS"

Kegiatan pelatihan Penggunaan Aplikasi "POS"dapat dikatakan berhasil karena indikator dan tolok ukur kegiatan tercapai. Namun peserta tidak cukup mampu menangani masalah teknis penggunaan sistem POS.

3. Implementasi aplikasi POS pada usaha mitra

Kegiatan pelatihan Penggunaan Aplikasi "POS"dapat dikatakan cukup berhasil karena indikator dan tolok ukur kegiatan tidak tercapai seluruhnya. Implmentasi sistem membutuhkan perencanaan dan kemauan keras mitra dan didukung oleh semua staf dan karyawan.

Rincian evaluasi kegiatan ini dapat dilihat pada tabel berikut ini. 
Tabel 1. Evaluasi Kegiatan

\begin{tabular}{|c|c|c|c|c|c|c|}
\hline Kegiatan & Tujuan & Kriteria Evaluasi & Indikator & Tolok Ukur & Realisasi & Pencapaian \\
\hline \multirow[t]{3}{*}{$\begin{array}{l}\text { Pelatihan } \\
\text { Akuntansi Dasar }\end{array}$} & $\begin{array}{l}\text { Memberikan memberikan } \\
\text { pengetahuan dan technical skills } \\
\text { di bidang akuntansi dasar, } \\
\text { khususnya akuntansi pendapatan } \\
\text { dan beban }\end{array}$ & 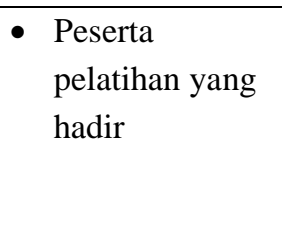 & $\begin{array}{l}\text { Jumlah Peserta } \\
\text { Hadir }\end{array}$ & $>75 \%$ & $\begin{array}{l}7 \text { undangan, } \\
\text { hadir } 7 \text { undangan }\end{array}$ & $100 \%$ \\
\hline & $\begin{array}{l}\text { Memberikan pengetahuan } \\
\text { bagaimana pengelolaan } \\
\text { administrasi keuangan }\end{array}$ & $\begin{array}{l}\text { - Peserta } \\
\text { Pelatihan yang } \\
\text { mengajukan } \\
\text { pertanyaan }\end{array}$ & $\begin{array}{l}\text { Jumlah Peserta } \\
\text { Bertanya }\end{array}$ & $>50 \%$ & $\begin{array}{l}\text { Semua Peserta } \\
\text { bertanya dan } \\
\text { menjawab }\end{array}$ & $100 \%$ \\
\hline & $\begin{array}{l}\text { - Dapat menyusun laporan Laba } \\
\text { Rugi }\end{array}$ & $\begin{array}{l}\text { - Laporan laba } \\
\text { rugi yang benar } \\
\text { disusun dari } \\
\text { contoh soal }\end{array}$ & $\begin{array}{l}\text { Jumlah laporan } \\
\text { Laba rugi } \\
\text { terselesaikan }\end{array}$ & Min 2 LR & $\begin{array}{l}7 \text { Lapoaran Laba } \\
\text { Rugi }\end{array}$ & $100 \%$ \\
\hline \multirow[t]{2}{*}{$\begin{array}{l}\text { Pelatihan } \\
\text { Penggunaan } \\
\text { Aplikasi "POS" }\end{array}$} & - Memperkenalkan sistem POS & $\begin{array}{l}\text { - Peserta } \\
\text { pelatihan yang } \\
\text { mengajukan } \\
\text { pertanyaan }\end{array}$ & $\begin{array}{l}\text { Jumlah Peserta } \\
\text { Bertanya }\end{array}$ & $>50 \%$ & $\begin{array}{l}\text { Semua Peserta } \\
\text { bertanya dan } \\
\text { menjawab }\end{array}$ & $100 \%$ \\
\hline & $\begin{array}{l}\text { - Memberikan technical skills } \\
\text { untuk membuat setting awal } \\
\text { database pada sistem POS }\end{array}$ & $\begin{array}{l}\text { - Peserta yang } \\
\text { mencoba } \\
\text { membuat file } \\
\text { database awal }\end{array}$ & $\begin{array}{l}\text { Jumlah database } \\
\text { yang selesai } \\
\text { dibuat }\end{array}$ & $\begin{array}{l}\text { Min } 2 \text { file } \\
\text { database }\end{array}$ & 3 file database & $100 \%$ \\
\hline
\end{tabular}


- Memberikan gambaran operasional POS sesungguhnya melalui simulasi

- Memberikan technical skills untuk menangani berbagai masalah teknis dan non teknis pada aplikasi POS

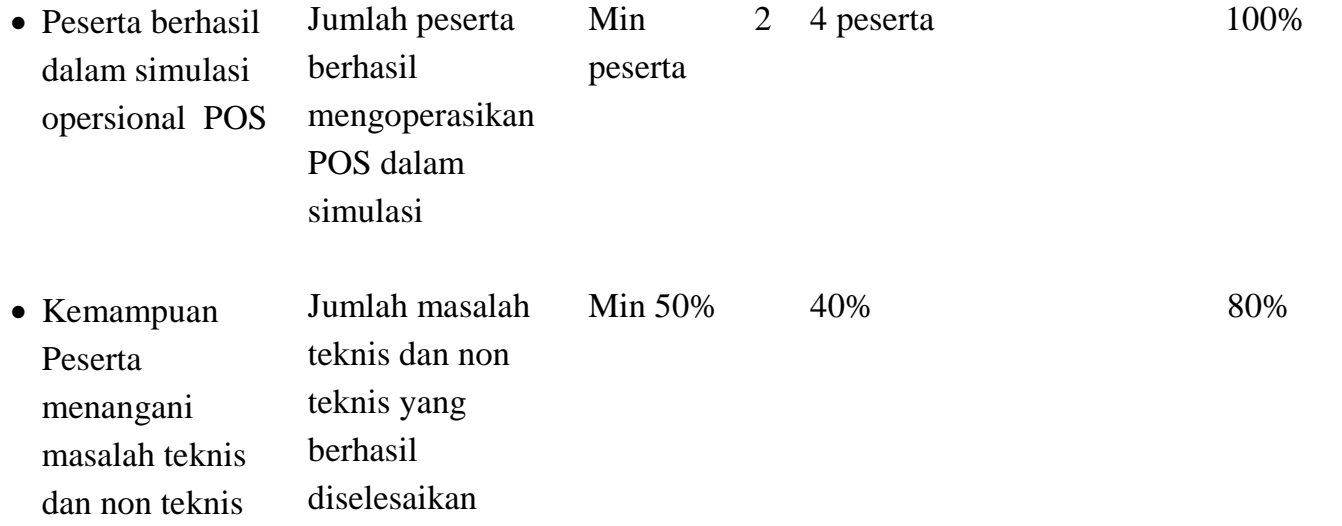




\section{KESIMPULAN DAN SARAN}

\section{KESIMPULAN}

Kegiatan ini berhasil menerapkan suatu metode yang dirancang khusus untuk orang awam yang kurang mengerti ilmu akuntansi. Metode tersebut dinamakan puzzle drilling method. Metode ini terbukti efektif untuk mengubah mindset secara cepat. Pada awalnya semua mitra menyusun laporan laba rugi dengan konsep uang keluar dan uang masuk, namun dengan metode ini mitra dengan cepat menyadari kesalahpahaman dan ketidaktahuan mereka mengenai laporan laba rugi.

\section{SARAN}

Untuk keberhasilan kegiatan ini dimasa depan, maka:

1. Kegiatan ini harus dilanjutkan pada tahun kedua.

2. Skema pendanaan yang lebih fleksibel dan tepat waktu sehingga juga fleksibel terhadap waktu mitra.

3. Bekerja sama dengan vendor sistem informasi akuntansi untuk mendukung penyebarluasan penerapan informasi dan teknologi yang mendukung dunia usaha.

\section{UCAPAN TERIMA KASIH}

Ucapan terima kasih yang sebesar-besarnya disampaikan kepada mitra utama Ibu Rolly Sartika dari Toko Keluarga KZ Abidin, Bengkulu dan seluruh mitra kegiatan yang mendukung kegiatan ini.

\section{DAFTAR PUSTAKA}

Anonim. 2009, Laporan Bank Indonesia.

Nurazi, Ridwan, Fitri Santi, dan Siti Aisyah, 2009, Financial Management dan Peningkatan Profitabilitas Usaha Kecil Menengah di Kota Bengkulu, Laporan Hasil Penelitian Hibah Bersaing. 